\title{
ОСОБЕННОСТИ МИНЕРАЛЬНОГО СОСТАВА УГЛЕРОДИСТЫХ СЛАНЦЕВ РЫЛЬСКОЙ РИФТОГЕННОЙ СТРУКТУРЫ КМА
}

\section{Токарева B.A.}

Воронежский государственный университет, Воронеж, vikaczech@gmail.com

На территории Воронежского кристаллического массива углеродсодержащие породы встречаются в составе докембрийских метаморфических комплексов различного возраста. Максимального развития углеродсодержащие породы достигают в оскольской серии нижнего протерозоя, которая перекрывает железорудную курскую серию. Состав и строение оскольской серии характеризуется ритмичной, неоднократно повторяющей сменой конгломератов, гравелитов и метапесчаников, переходящих к верхам разреза в карбонатно-слюдистые сланцы с горизонтами амфиболитов, метаморфизованных доломитов и известняков, широким развитием углеродсодержащих пород и вулканитов. Отложения оскольской серии накапливались только в наиболее крупных структурах с длительным устойчивым прогибанием: Тим-Ястребовской, Белгородской, Михайловской, Волотовской, Рыльской [Чернышов, 1997].

Объектом исследований в настоящей работе выступают углеродистые сланцы оскольской серии, вскрытые буровыми скважинами в пределах Стрекаловского участка Рыльской структуры КМА. Разновозрастные стратифицированные углеродистые толщи различных регионов Земли являются уникальными источниками цветных, редких и благородных металлов, что обуславливает интерес к изучаемым породам.
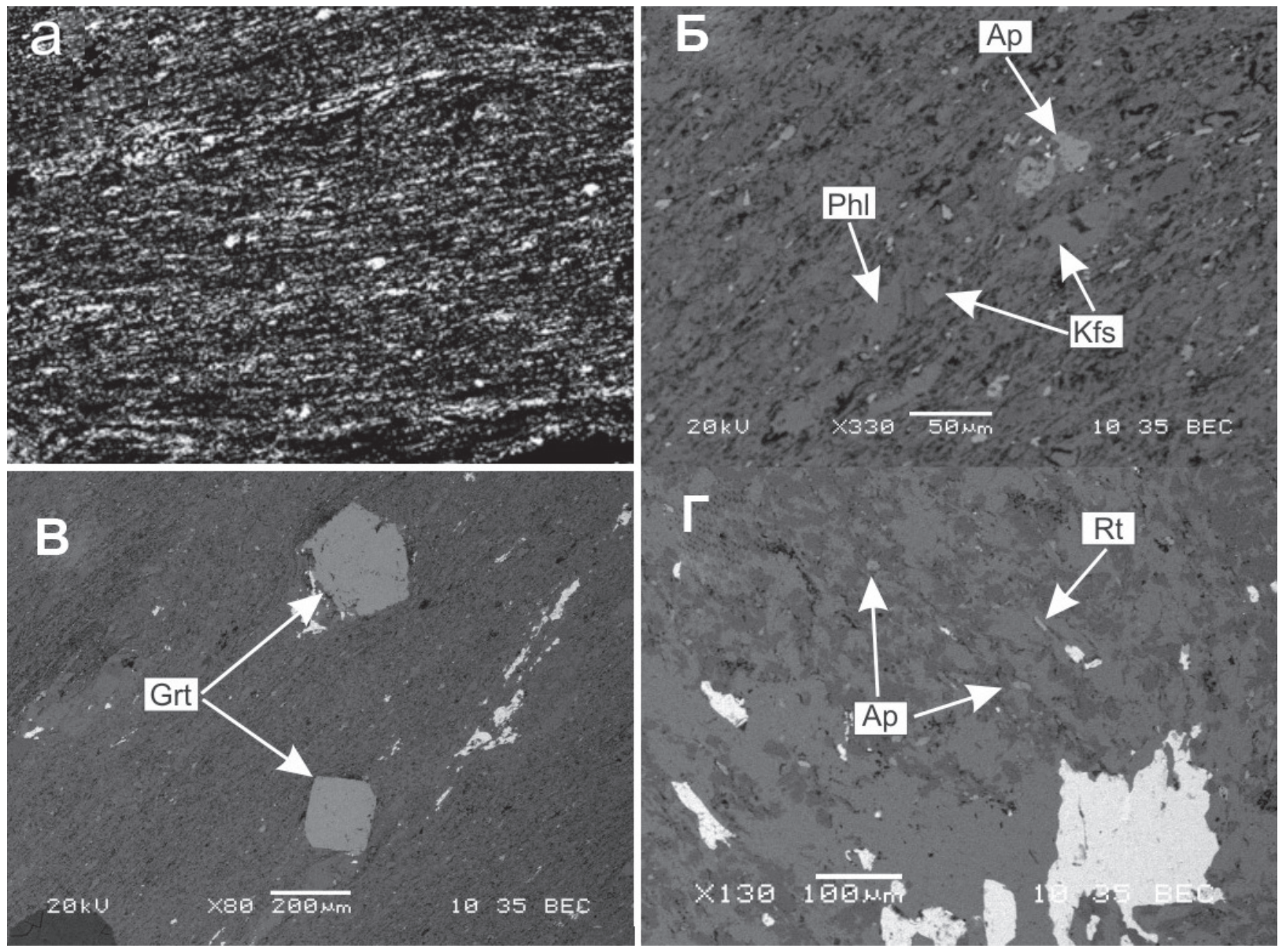

Рис. 1. Структурно-текстурные особенности, породообразующие и акцессорные минералы углеродистых сланцев Рыльской рифтогенной структуры КМА.

а) сланцеватая текстура, б) Ap - апатит, Phl - флогопит, Kfs - калиевый полевой шпат, в) Grt - гранат, Ap апатит г) Rt - рутил; сокращенные обозначения минералов даны по [5]. 


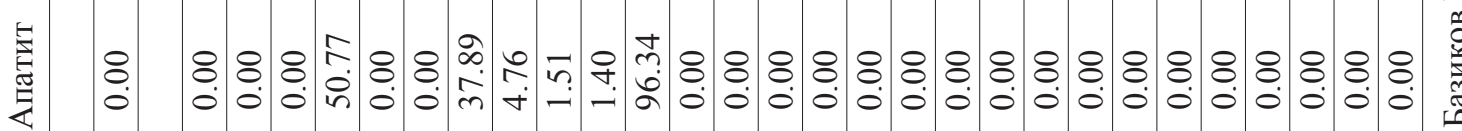

罣

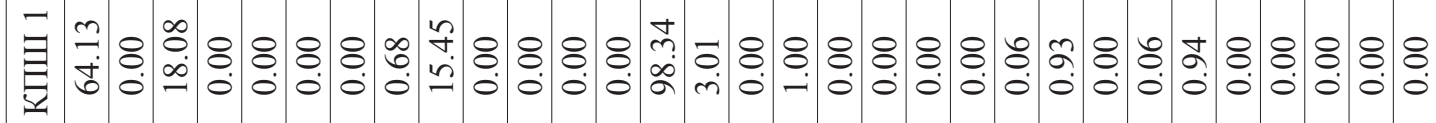

วิํㅇ

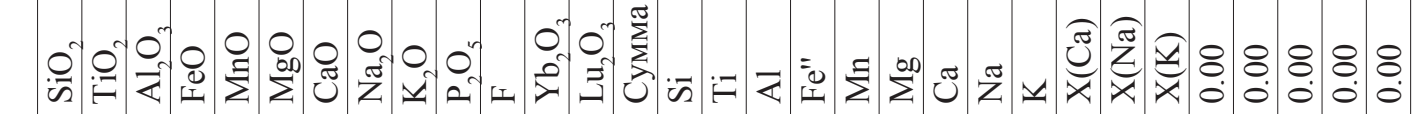

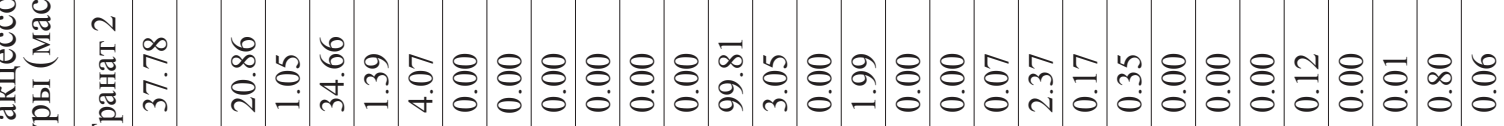

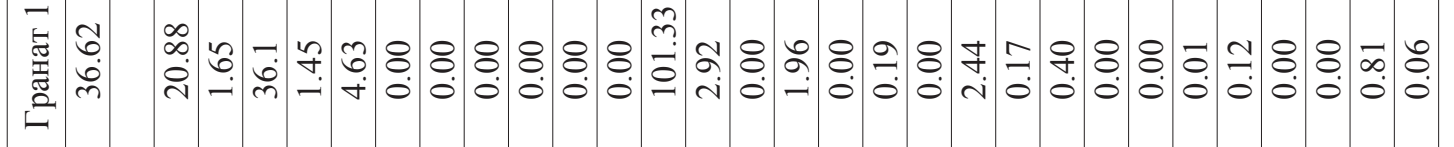

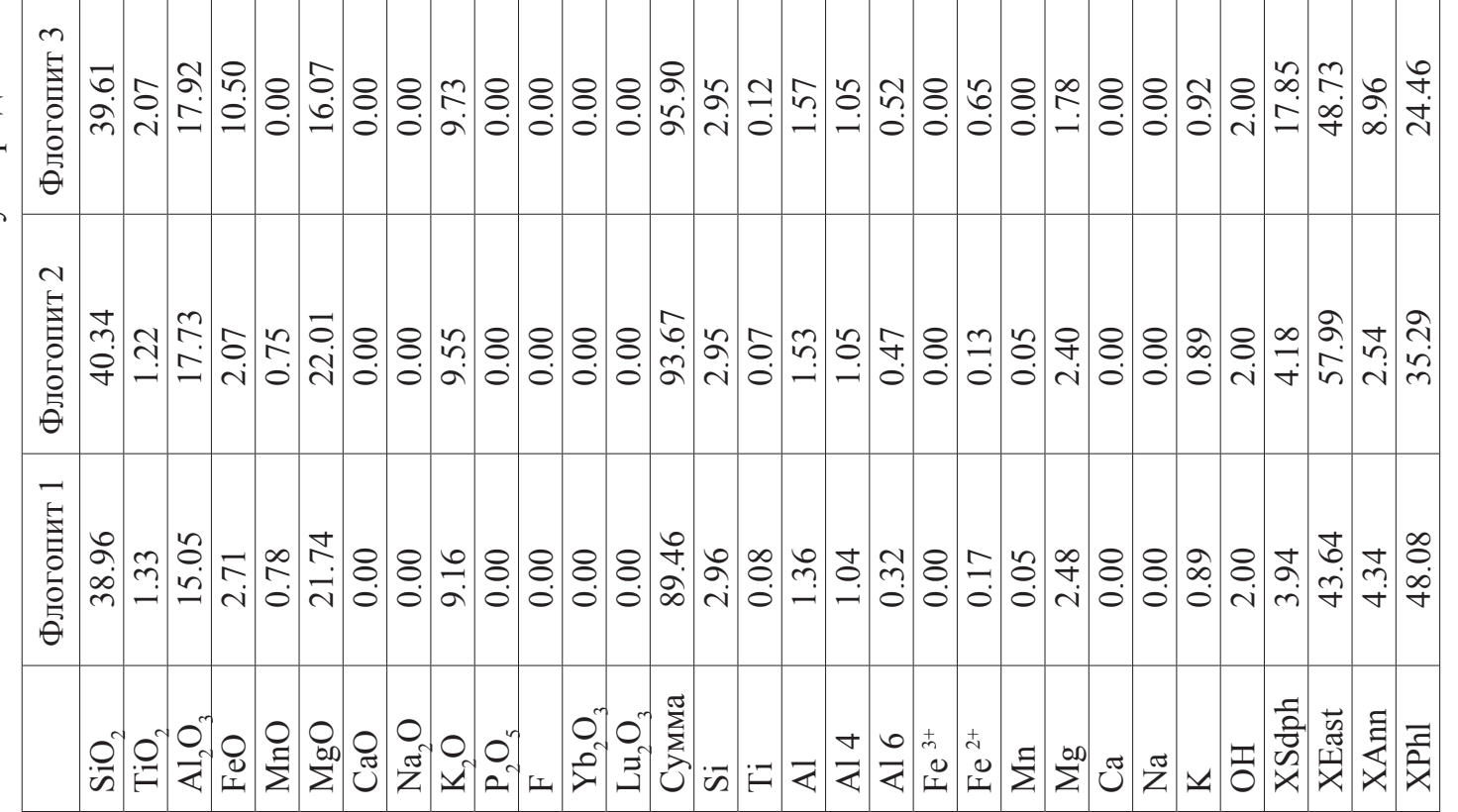

要

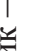
E $\hat{s}$ 곤 芯 惫 
Макроскопически углеродистые сланцы Рыльской структуры представляют собой темносерые до черных породы. Для них характерны микрозернистая, гранобластовая, лепидобластовая (рис. 1 a), порфиробластовая структуры. Текстура пород сланцеватая (рис. 1 a), часто плойчатая. Главными породообразующими минералами сланцев являются кварц, слюды (серицит, флогопит, мусковит), калиевый полевой шпат (КПШ), а также гранаты. В отдельных участках породы интенсивно обогащены углеродистым веществом (графитом), что затрудняет определение состава пород [Скулков, 1985]. В качестве второстепенных и акцессорных минералов выступают карбонаты, апатит, хлорит.

Изучение минерального состава межрудных сланцев проводилось по прозрачно-полированным шлифам с использованием поляризационного и сканирующего электронного микроскопов, а также микрорентгеноспектрального анализа. Ниже приводится подробное описание минералов, входящих в состав изучаемых пород.

Во всех типах углеродистых сланцев присутствует кварц, который слагает основную массу породы. В срастании с углеродистым веществом минерал плохо распознаваем под микроскопом, поэтому дать оценку его количеству затруднительно. Зачастую содержание кварца около 10-20\%. Зерна кварца имеют неправильную, уплощенную или изометричную форму. В шлифах кварц имеет низкий рельеф, в проходящем свете бесцветный, в скрещенных николях серый, характеризуется «облачным погасанием», когда различные нечеткие участки зерен гаснут с небольшим опережением или отставанием от других, заниженным двупреломлением, серыми и темно - серыми цветами интерференции. Поверхность часто не гладкая, содержит мелкие включения других минералов, чаще всего рудных. Размер зерен варьирует от 0.05-0.08 мм.

Слюдистая составная часть микрочешуйчатая, удлиненно-пластинчатые зерна располагаются параллельно со сланцеватостью (0.04-0.07 мм), обычно разбросанные в ткани (рис. 1 б) или образуют струеподобные скопления. Количество слюды в шлифах около 45-50 \%. Слюда обладает совершенной спайностью, светлой окраской от бледно-коричневого по $\mathrm{N}_{\mathrm{g}}$ до бесцветного по $\mathrm{N}_{\mathrm{p}}$, слабым плеохроизмом. По результатам микрорентгеноспектрального анализа установлено, что слюда представлена флогопитом с переменным химическим составом (табл. 1).

При изучении породообразующих минералов сланцев под микроскопом были диагностированы порфиробласты гранатов, представленные идиоморфными кристаллами (рис. 1 в). Это темнобурые до коричневатых зерна кубической сингонии. В шлифах гранат изотропный, с высоким рельефом и резкой шагреневой поверхностью. По химическому составу (табл. 1) отвечает спессартину (более 90 \% Sps), зональность кристаллов не выявлена.

В составе сланцев также установлены калиевые полевые шпаты (табл. 1, рис. 1 б). Совместно с кварцем и слюдами они слагают основную ткань породы. Представлены прямоугольными, изометричными зернами размером 0.02-0.05 мм. В шлифах прозрачные, цвета интерференции низкие, серые. Показатель преломления ниже канадского бальзама и соответственно, кварца, с которым его, в силу маленького размера зерен, можно спутать. Содержание в породе составляет около 15 \%.

Из акцессорных минералов в шлифах уверенно диагностируется только апатит, представленный зернами неправильной, изометричной формы (рис. 1 в). Рельеф высокий, шагреневая поверхность. Цвета интерференции темно-серые, погасание прямое. Размер зерен составляет 0.015-0.03 мм. По результатам микрорентгеноспектральных исследований установлено, что данный минерал содержит в своем составе тяжелые лантаноиды и представлен фторапатитом (табл. 1).

В исследуемых породах также присутствует рутил, представленный тонкими игольчатыми кристаллами вытянутой формы. Маленький размер зерен (10-20 мкм) затрудняет диагностику в шлифах, но данный минерал был уверенно диагностирован при микрорентгеноспектральных исследованиях.

Среди рудных минералов сланцев наибольшим распространением пользуются пирит и пирротин, содержание и взаимоотношение которых в породах значительно изменяется в различных образцах, колеблясь от 5-7 \% до 30-35\%. Остальные акцессорные минералы, в том числе и рудные, 
представленные сфалеритом, халькопиритом, магнетитом, цирконом, ставролитом были уверенно диагностированы лишь при изучении тяжелой фракции минералов сланцев.

Таким образом, в результате проведенных исследований минерального состава углеродистых сланцев Рыльской рифтогенной структуры, с помощью микрорентгеноспектрального анализа впервые определены химические составы главных, второстепенных и акцессорных минералов, рассчитаны минальные соотношения основных породообразующих минеральных фаз. Установлено присутствие среди главных породообразующих минералов магнезиальной слюды - флогопита, а не серицита, как считалось ранее в работах предшественников, а также калиевого полевого шпата в ткани пород, диагностика которого оптическими методами была затруднена.

Полученные новые данные об особенностях минерального состава углеродистых сланцев имеют важное значение для установления генезиса предшествующих осадков и палеофациальных обстановок накопления изучаемых пород.

\section{Литература}

1. Винчелл А.Н. Оптическая минералогия / А.Н.Винчелл, Г.Винчелл. Москва. Изд-во иностранной литературы. 1953. $561 \mathrm{c.}$

2. Дир У.А. Породообразующие минералы / У.А. Дир, Р.А. Хауи, Дж. Зусман. Изд-во: МИР. Москва. 1965. $371 \mathrm{c}$.

3. Модель геодинамического развития Воронежского кристаллического массива в раннем докембрии / Н.М. Чернышов [и др.] // Геотектоника. 1997. № 3. С. 21-30.

4. Скулков Н.А. Геологическое строение и полезные ископаемые Стрекаловского участка (северо-запад КМА). 1985 / Н.А. Скулков. Фонды курского филиала ФБУ «ТФГИ по Центральному федеральному округу».

5. Donna L. Whitney, Bernard W. Evans. Abbreviations for names of rock-forming minerals. American Mineralogist. 2010. V. 90. P.185-187. 